\title{
Kepatuhan, Pemeriksaan, Penagihan dan Penerimaan Terhadap Pajak dengan Peran Account Representative Sebagai Pemoderasi
}

\author{
Artika Wulan Agustin'1, Darmansyah², Suyanto ${ }^{3}$ \\ 1,2 Universitas Pancasila, Jakarta, Indonesia \\ ${ }^{3}$ Sekolah Tinggi Ilmu Ekonomi IPWI, Jakarta, Indonesia
}

\section{INFO ARTIKEL JEL Classification :}

$\mathrm{H} 21, \mathrm{H} 25$

Keywords :

compliance, tax audit, tax collection, account representative, tax revenue

\begin{abstract}
The effort to increase tax revenue is an important issue because the source of funding for national development comes from tax revenue. This study aims to look at the effect of Compliance, Tax Audit and Tax Collection on Tax Revenue which is moderated by the Role of Account Representatives. The sample in this study consisted of 32 taxpayers registered in Sixth Foreign Investment Tax Office who were issued Tax Underpayment Assessment and tax appeal letter every year during 2017-2019. The type of data used is quantitative data from secondary data sources. The data analysis technique used is path analysis using the SEM model with the WarpPLS 5.0 program. Based on the results of the study note that taxpayer compliance has no effect on tax revenue. Whereas Tax Audits and Tax Collection affect the tax revenue. Tax audits that are moderated by the role of Account Representatives affect tax revenue. Meanwhile, collections that are moderated by the role of Account Representatives do not affect tax revenues.
\end{abstract}

\begin{abstract}
ABSTRAK
Upaya untuk meningkatkan penerimaan pajak adalah masalah penting karena sumber pendanaan untuk pembangunan nasional berasal dari pendapatan pajak. Penelitian ini bertujuan untuk melihat pengaruh Kepatuhan, Audit Pajak dan Pengumpulan Pajak terhadap Penerimaan Pajak yang dimoderasi oleh Peran Perwakilan Akun. Sampel dalam penelitian ini terdiri dari 32 wajib pajak terdaftar di Kantor Pajak Investasi Asing Keenam yang menerbitkan Surat Ketetapan Pajak Kurang Bayar dan surat banding pajak setiap tahun selama 2017-2019. Jenis data yang digunakan adalah data kuantitatif dari sumber data sekunder. Teknik analisis data yang digunakan adalah analisis jalur menggunakan model SEM dengan program WarpPLS 5.0. Berdasarkan hasil penelitian diketahui bahwa kepatuhan wajib pajak tidak berpengaruh terhadap penerimaan pajak. Sedangkan Audit Pajak dan Pengumpulan Pajak mempengaruhi penerimaan pajak. Audit pajak yang dimoderasi oleh peran Perwakilan Akun memengaruhi pendapatan pajak. Sementara itu, koleksi yang dimoderasi oleh peran Perwakilan Akun tidak memengaruhi pendapatan pajak.
\end{abstract}

\section{Pendahuluan}

Negara Indonesia adalah negara kepulauan dengan kondisi geografis yang luas dan demografis penduduk Indonesia yang sangat banyak, sehingga memerlukan sumber dana yang besar untuk membiayai pembangunan agar Negara Kesatuan 
Republik Indonesia menjadi negara yang sejahtera

Sebagaimana disampaikan oleh Menteri Keuangan Republik Indonesia dalam sambutan seminar Kantor Pusat DJP pada tanggal 11 Juli 2018, beliau berpendapat bahwa "untuk menjalankan suatu negara dibutuhkan sumber pendanaan yang besar. Karena itulah pendiri Bangsa sebelum Kemerdakaan Indonesia 17 Agustus 1945 menentukan pajak guna menjalankan negara" Negara kita sangat membutuhkan Pajak untuk membiayai pembangunan infrastruktur. Sehingga kita perlu untuk kembali menyadari betapa krusialnya Pajak untuk membiayai negara kita yang sangat besar dengan jumlah penduduk yang sangat banyak.

Salah satu prinsip dalam pemungutan pajak menurut Fritz Neumark seperti diceritakan oleh Nurmantu (2003 : 91) adalah revenue productivity, dimana terdiri dari dua hal yakni the principle of adequacy dan the principle of adaptability . Dalam principle of adequacy pada intinya bahwa sistem perpajakan nasional seharusnya dapat menjamin penerimaan negara untuk membiayai semua pengeluaran negara. Sekiranya penerimaan yang berasal dari pajak yang telah dapat memenuhi semua pengeluaran negara, maka negara tersebut akan dapat dikelompokkan menjadi negara yang sangat maju dan makmur.

Gambar 1

Realisasi Penerimaan Pajak KPP PMA Enam

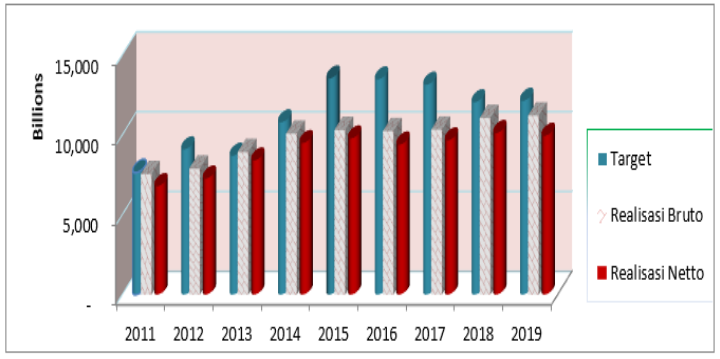

Berdasarkan data KPP Penanaman Modal Asing Enam diatas diketahui bahwa meskipun penerimaan bertumbuh, KPP Penanaman Modal Asing Enam (KPP PMA Enam) masih belum dapat mencapai target penerimaan pajak. Pertumbuhan penerimaan pajak 9 (sembilan) tahun terakhir cenderung menurun. Bahkan pada tahun 2016 mengalami pertumbuhan negative yaitu $-5,09 \%$. Setelah tahun 2016, pertumbuhan mulai meningkat kembali, namun taget penerimaan pajak masih belum tercapai.

Menurut Soenaryo (2017) kepatuhan pajak berpengaruh terhadap penerimaan $\mathrm{PPh}$ badan. Kepatuhan pajak yang tidak meningkat akan mengancam upaya pemerintah untuk meningkatkan kesejahteraan masyarakat Chau (2009) (dalam Mahendra \& Sukharta, 2014). Hal ini dikarenakan tingkat kepatuhan pajak secara tidak langsung mempengaruhi ketersediaan pendapatan untuk belanja (Jung, 1999) (dalam Mahendra \& Sukharta, 2014). Kepatuhan wajib pajak menjadi sebuah syarat agar penerimaan negara meningkat. Penerimaan pajak pada Kantor Pelayanan Pajak akan meningkat apabila wajib pajak semakin patuh dalam melaporkan serta melunasi kewajiban perpajakannya Agustina (2008) (dalam Mahendra \& Sukharta, 2014). Kepatuhan Wajib Pajak yang diukur dari jumlah penyampaian SPT Tahunan berpengaruh signifikan terhadap penerimaan pajak di Kantor Pelayanan Pajak pada Kantor Wilayah Sumatera Selatan, Barat dan Tenggara (Sultan, 2013).

Pemeriksaan pajak menjadi sangat penting yang harus dilakukan oleh DJP karena pemeriksaan pajak berperan dalam hal penambahan devisa negara, pembiayaan negara serta pembangunan nasional (Taroreh, 2013), jika pemeriksaan pajak tinggi maka penerimaan negara juga akan semakin tinggi (Saputro, 2012) (dalam Wulandari, 2015).

Penagihan pajak merupakan salah satu upaya pemerintah dalam meningkatkan penerimaan pajak dari sanksi pajak yang telah diterbitkan oleh pemeriksa pajak atau Account Representative. Penelitian Trisnayanti (2015) menyatakan bahwa penagihan pajak berpengaruh signifikan positif terhadap penerimaan PPN pada KPP Pratama Bandung Utara. Penagihan pajak menjadi tonggak bagi DJP dalam mengemplang wajib pajak yang nakal. Dengan dilakukan penagihan pajak secara aktif dan pasif diharapkan pencairan tunggakan pajak yang disebabkan karena wajib pajak tidak mematuhi aspek material peraturan perpajakan, dapat direalisasikan. Hal ini akan memberikan peningkatan pada penerimaan pajak (Rahayu, 2017: 297). 
Selain menigkatkan kesadaran wajib pajak, upaya lain yang dilakukan untuk meningkatkan penerimaan negara adalah dengan melakukan penggalian potensi oleh Account Representative. Peran Account Representative yang digambarkan melalui kinerjanya dalam penerbitan Surat Himbauan atau SP2DK, menurut Wahyuni (2015) berpengaruh terhadap penerimaan pajak. Penggalian potensi dilakukan dengan mencari potensi pajak yang belum dibayarkan oleh wajib pajak. Penggalian potensi merupakan upaya Kantor Pelayanan Pajak dalam mengedukasi wajib pajak tentang berbagai kewajiban perpajakan yang menjadi tanggung jawabnya. Kegiatan penggalian potensi juga merupakan salah satu cara untuk mengurangi tax allowance yang dilakukan oleh wajib pajak.

Research gap dalam penelitian terdahulu menunjukan beberapa hal. Penelitian Kastolani \& Ardiyanto (2017) menunjukan kepatuhan wajib pajak badan tidak berpengaruh terhadap penerimaan pajak penghasilan. Penelitian Sari (2015) menunjukan bahwa pemeriksaan pajak diamati dari jumlah pajak penghasilan pasal 25 surat penagihan pajak yang dikeluarkan untuk wajib pajak pribadi, tidak berpengaruh. Sakti (2019) dalam penelitiannya menyatakan Penagihan pajak tidak berpengaruh terhadap penerimaan pajak Orang Pribadi. Penelitian Parmono (2016) menunjukan secara keseluruhan kontribusi SP2DK terhadap penerimaan pajak KPP Pratama Manado tergolong sangat kurang.

\section{Telaah Teori dan Pengembangan Hipotesis}

\section{Stewardship Theory}

Pada penelitian ini, peneliti menggunakan Stewardship Theory sebagai Grand Theory. Menurut Donaldson dan Davis ( 1991), Stewardship theory menjelaskan mengenai situasi manajemen tidaklah termotivasi oleh tujuan-tujuan individu, melainkan lebih ditujukan pada sasaran hasil utama mereka untuk kepentingan organisasi. Teori tersebut mengasumsikan bahwa adanya hubungan yang kuat antara kepuasan dan kesuksesan organisasi. Teori stewardship menggambarkan hubungan antara pemerintah (steward) sebagai pengelola penerimaan
Negara berupa pajak dan rakyat (Principal) sebagai subjek sumber penerimaan Negara. Stewardship Theory dalam perpajakan tergambar dari hubungan rakyat dan pemerintah dalam menghimpun pajak. Sumbangsih rakyat kepada negara berupa penyetoran pajak yang akan digunakan untuk kemakmuran rakyat. Rakyat dipercaya untuk menghitung sendiri pajak yang terutang dan menyetorkannya kepada negara. Pajak yang telah dibayarkan oleh negara akan digunakan untuk mensukseskan tujuan Negara untuk mencapai kemakmuran rakyat.

\section{Penerimaan Pajak}

Sesuai dengan Undang-Undang Nomor 28 Tahun 2007 tentang Perubahan Ketiga atas Undang-Undang Nomor 6 Tahun 1983 tentang "Ketentuan Umum dan Tata Cara Perpajakan", pasal 1 butir 1 berisi tentang definisi pajak, yaitu "pajak adalah kontribusi wajib kepada negara yang terutang oleh orang pribadi atau badan yang bersifat memaksa berdasarkan undang-undang dengan tidak mendapatkan imbalan secara langsung dan digunakan untuk keperluan negara bagi sebesar-besarnya kemakmuran rakyat."

Definisi penerimaan pajak menurut Hutagaol (2007:325) adalah : "Penerimaan pajak merupakan sumber penerimaan yang dapat diperoleh secara terusmenerus dan dapat dikembangkan secara optimal sesuai kebutuhan pemerintah serta kondisi masyarakat."

\section{Kepatuhan Wajib Pajak}

Menurut Gunadi (2013:94): "Dalam hal ini diartikan bahwa Wajib Pajak mempunyai kesediaan untuk memenuhi kewajiban perpajakan sesuai dengan aturan yang berlaku tanpa perlu diadakan pemeriksaan, investasi seksama, peringatan ataupun ancaman dan penerapan sanksi baik hukum maupun administrasi”.

Menurut Nurmantu (2003), terdapat dua macam kepatuhan yaitu kepatuhan formal dan material. Kepatuhan formal adalah suatu keadaan dimana wajib pajak memenuhi kewajiban secara formal sesuai dengan ketentuan perpajakan. Kepatuhan wajib pajak dalam membayar pajak secara formal dapat dilihat dari aspek kesadaran wajib pajak untuk mendaftarkan diri, ketepatan waktu wajib pajak untuk mendaftarkan diri, membayar 
pajak dan melakukan pelaporan SPT. Kepatuhan material lebih mencakup yaitu pemenuhan secara substantif isi dan jiwa ketentuan perpajakan. Kepatuhan material adalah suatu keadaan dimana wajib pajak secara substantif (hakekat) memenuhi semua ketentuan material perpajakan, yakni sesuai isi dan jiwa undang-undang perpajakan.

Pengukuran kepatuhan wajib pajak secara formal maupun material lebih kepada kesadaraan wajib pajak sebagai warga negara untuk melakukan kewajibannya bagi kemajuan bangsanya. Dengan tingginya tingkat kepatuhan maka pendapatan dari sektor pajak akan semakin meningkat sehingga memperlancar pembangunan bangsa ini.

\section{Pemeriksaan Pajak}

Pengertian pemeriksaan pajak menurut Ilyas dan Burton, (2013:169) adalah "Pemeriksaan adalah serangkaian kegiatan menghimpun dan mengolah data, keterangan, dan/atau bukti yang dilaksanakan secara objektif dan profesional berdasarkan suatu standar pemeriksaan untuk menguji kepatuhan pemenuhan kewajiban perpajakan dan/atau untuk tujuan lain dalam rangka melaksanakan ketentuan peraturan perundang-undangan perpajakan".

Hidayat (2013:11) menyebutkan bahwa beberapa kebijakan umum dalam pemeriksaan pajak sebagai berikut :"

a) Setiap wajib pajak memiliki peluang yang sama untuk diperiksa;

b) Setiap pemeriksaan yang dilaksanakan harus dilengkapi dengan surat perintah pemeriksaan pajak yang mencantumkan tahun pajak yang diperiksa;

c) Pemeriksaan dapat dilaksanakan oleh kantor pusat Direkrtorat Jenderal Pajak, kantor wilayah Direktorat Jenderal Pajak, atau Kantor Pelayanan Pajak;

d) Pemeriksaan ulang terhadap jenis atau tahun pajak yang sama, tidak diperkanankan, kecuali dalam hal-hal tertentu;

e) Buku-buku, catatan-catatan dan dokumen lain yang akan dipinjam dari wajib pajak dalam pelaksanaan pemeriksaan tidak harus yang asli, dapat juga misalnya berupa fotokopi yang sesuai dengan aslinya;

f) Pemeriksaan dapat dilakukan di Kantor pemeriksaan (yaitu untuk pemeriksaan sederhana kantor) atau di tempat wajib pajak (untuk pemeriksaan sederhana lapangan atau pemeriksaan lengkap);

g) Jangka waktu pemeriksaan terbatas;

h) Dapat dilakukan perluasan pemeriksaan, baik untuk tahun-tahun sebelumnya maupun tahun sesudahnya, yaitu dalam hal tertentu;

i) Setap hasil pemeriksaan harus diberitahukan kepada wajib pajak secara tertulis, yaitu mengenai hal-hal yang berbeda antara surat pemberitahuan (SPT) wajib pajak dan hasil pemeriksaan, dan selanjutnya untuk dianggap oleh wajib pajak."

\section{Penagihan Pajak}

Menurut Pasal 1 Peraturan Menteri Keuangan Republik Indonesia Nomor 24/PMK.03/2008 tentang Tata Cara Pelaksanaan Penagihan Dengan Surat Paksa dan Pelaksnaan Penagihan Seketika dan Sekaligus, penagihan pajak adalah serangkaian tindakan agar penanggung pajak melunasi utang pajak dan biaya penagihan pajak dengan cara menegur atau memperingatkan, melaksanakan penagihan seketika dan sekaligus, memberitahukan Surat Paksa, mengusulkan pencegahan, melaksanakan penyitaan, melaksanakan penyanderaan dan menjual barang yang telah disita.

Dasar penagihan pajak adalah Surat Tagihan Pajak, Surat Ketetapan Pajak Kurang Bayar, Surat Ketetapan Pajak Kurang Bayar Tambahan, Surat Keputusan Pembetulan, Surat Keputusan Keberatan, Putusan Banding, dan Putusan Peninjauan Kembali, yang menyebabkan jumlah pajak yang masih harus dibayar bertambah.

Pasal 1 Peraturan Menteri Keuangan nomor 24/PMK.03/2008 menyebutkan bahwa Penagihan seketika dan sekaligus adalah tindakan penagihan pajak yang dilaksanakan oleh jurusita pajak kepada penanggung pajak tanpa menunggu tanggal jatuh tempo pembayaran yang meliputi seluruh utang 
pajak dari semua jenis pajak, masa pajak, dan tahun pajak.

\section{Account Representative}

Account Representative Menurut Hutagaol (2007:22) adalah "Pegawai Direktorat Jenderal Pajak (DJP) yang diberi kepercayaan, wewenang, dan tanggung jawab untuk memberikan pelayanan, pembinaan, dan pengawasan secara langsung kepada wajib pajak".

Account Representative memiliki tugas :

a) Account Representative yang menjalankan fungsi pelayanan dan konsultasi Wajib Pajak mempunyai tugas:

1) Melakukan proses penyelesaian permohonan Wajib Pajak;

2) Melakukan proses penyelesaian usulan pembetulan ketetapan pajak;

3) Melakukan bimbingan dan konsultasi teknis perpajakan kepada Wajib Pajak; dan

4) Melakukan proses penyelesaian usulan pengurangan Pajak Bumi dan Bangunan.

b) Account Representative yang menjalankan fungsi pengawasan dan penggalian potensi Wajib Pajak mempunyai tugas:

1) Melakukan pengawasan kepatuhan kewajiban perpajakan Wajib Pajak;

2) Menyusun profil Wajib Pajak;

3) Analisis kinerja Wajib Pajak; dan

4) Rekonsiliasi data Wajib Pajak dalam rangka intensifikasi dan himbauan kepada Wajib Pajak.

\section{Metode Penelitian}

Objek penelitian ini adalah Wajib Pajak yang terdaftar pada KPP PMA Enam. Teknik sampling yang digunakan adalah sampling jenuh yaitu teknik penentuan sampel bila seluruh anggota populasi digunakan sebagai sampel. Sampel penelitian ini berfokus pada Wajib pajak yang telah diterbitkan Surat Ketetapan Kurang Bayar atau Surat Tagihan Pajak, serta pernah diterbitkan himbauan oleh Account Representative dalam rentan waktu tahun 2017-2019 berturut-turut. Skala pengukuran yang digunakan adalah skala nominal dan skala rasio, sebagai berikut :

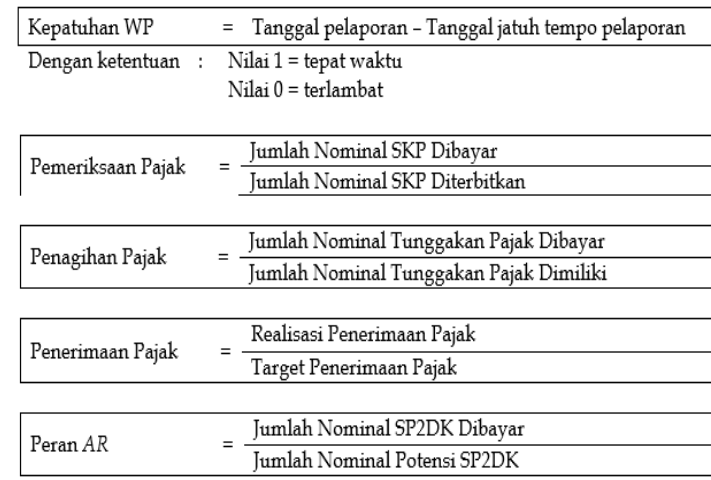

Teknik analisis data yang digunakan adalah analisis jalur (path analysis) menggunakan model SEM (Structural Equation Model) dengan program WrapPLS 5.0. Analisis jalur merupakan perluasan dari analisis regresi linear berganda, atau analisis jalur adalah penggunaan analisis regresi untuk menaksir hubungan kausalitas atas variabel (model casual) yang telah ditetapkan sebelumnya berdasarkan teori (Ghozali, 2006). Manfaat dari analisis jalur (path analysis) adalah untuk memberikan penjelasan atau explanation terhadap fenomena yang dipelajari atau permasalahan yang diteliti, membuat prediksi nilai variabel endogen (variable yang mempengaruhi) berdasarkan nilai variabel eksogen (variabel yang dipengaruhi), mengetahui faktor dominan yaitu penentu variablel eksogen mana yang berpengaruh dominan terhadap variable endogen.

\section{Hasil Penelitian dan Pembahasan}

Tabel 1 Statistik Deskriptif

\begin{tabular}{|llllllll|} 
& N & Min & Max & Mean & Std. Dev. & Skewness & E. Kurtosis \\
\hline Penerimaan & 96 & 0,020 & 3,170 & 0,985 & 0,525 & 1,515 & 3,604 \\
\hline Kepatuhan & 96 & 0,000 & 1,000 & 0,771 & 0,423 & $-1,289$ & $-0,339$ \\
\hline Pemeriksaan & 96 & 0,000 & 1,000 & 0,684 & 0,412 & $-0,752$ & $-1,196$ \\
\hline Penagihan & 96 & 0,000 & 1,000 & 0,708 & 0,379 & $-0,804$ & $-1,063$ \\
\hline Peran AR & 96 & 0,000 & 5159,76 & 133,19 & 636,95 & 6,302 & 42,52 \\
\hline
\end{tabular}

Nilai minimum penerimaan pajak adalah 0,020 dan maksimum 3,170 disimpulkan bahwa berdasarkan data sampel diketahui terdapat wajib pajak yang memiliki realisasi yang tinggi dari yang ditetapkan. Nilai kepatuhan 0 berarti wajib pajak tidak patuh, nilai 1 berarti patuh. Variabel pemeriksaan memiliki nilai minimum sebesar 0,000 berarti jumlah pajak terutang tidak atau belum dibayarkan oleh wajib pajak, nilai maksimum 1,000 berarti jumlah pajak terutang telah 
dilunasi seluruhnya. Penagihan pajak memiliki nilai minimum sebesar 0,000 tunggakan pajak tidak atau belum dilunasi sedangkan angka maksimun 1,000 berarti seluruh tunggakan pajak telah dilunasi. Peran AR memiliki nilai minimum 0,000 menunjukan bahwa atas potensi tidak terealisasi, Nilai maksimum 5159,76 terjadi karena pada saat menerbitkan Surat Himbauan, AR hanya memiliki data yang sedikit sehingga menghasilkan nilai potensi pajak yang kecil, namun dalam pelaksanaan penelitian ditemukan data yang menambah realisasi pembayaran pajak dari surat himbauan.

Tabel 2

Hasil Uji Validitas Konvergen dengan Nilai AVE

\begin{tabular}{|c|c|c|c|c|c|c|c|}
\hline & PP & Patuh & Periksa & Tagih & AR & $\mathrm{AR}^{*}$ Periksa & $\mathrm{AR}^{*}$ Tagih \\
\hline Avg. Var. Extrac & 1,00 & 1,00 & 1,00 & 1,00 & 1,00 & 1,00 & 1,00 \\
\hline Rule of Thumb & \multicolumn{7}{|c|}{$>0,5$} \\
\hline Valid/Tidak & Valid & Valid & Valid & Valid & Valid & Valid & Valid \\
\hline
\end{tabular}

Validitas konvergen ditentukan menggunakan parameter nilai AVE (Average Variance Extracted). Berdasarkan tabel nilai AVE untuk masing-masing indikator adalah 1,00 atau lebih dari 0,5 artinya bahwa variabel yang digunakan telah memenuhi kriteria validitas.

Tabel 3

Hasil Uji Validitas Diskriminasi dengan Nilai Cross Loading

\begin{tabular}{|llllllll|} 
& PP & Patuh & Periksa & Tagih & AR & AR*Periksa & AR $^{*}$ Tagih \\
\hline Penerimaan & $(1,00)$ & 0,00 & 0,00 & 0,00 & 0,00 & 0,00 & 0,00 \\
\hline Kepatuhan & 0,00 & $(1,00)$ & 0,00 & 0,00 & 0,00 & 0,00 & 0,00 \\
\hline Pemeriksaan & 0,00 & 0,00 & $(1,00)$ & 0,00 & 0,00 & 0,00 & 0,00 \\
\hline Penagihan & 0,00 & 0,00 & 0,00 & $(1,00)$ & 0,00 & 0,00 & 0,00 \\
\hline Peran AR & 0,00 & 0,00 & 0,00 & 0,00 & $(1,00)$ & 0,00 & 0,00 \\
\hline $\begin{array}{l}\text { Peran AR } \\
\text { Pemeriksaan }\end{array}$ & 0,00 & 0,00 & 0,00 & 0,00 & 0,00 & $(1,00)$ & 0,00 \\
\hline $\begin{array}{l}\text { Peran AR } \\
\text { Penagihan }\end{array}$ & 0,00 & 0,00 & 0,00 & 0,00 & 0,00 & 0,00 & $(1,00)$ \\
\hline Sumber : Data diolah tahun 2020 & & & & &
\end{tabular}

Validitas diskriminasi ditentukan dengan melihat cross loading dari setiap variabel dan dikategorikan memiliki validias diskriminan apabila memiliki nilai cross loading mencapai 0,7 . Untuk keseluruhan pengujian validitas diskriminan terlihat bahwa nilai cross loading setiap variabel indikator lebih besar terhadap variabel latennya dibandingkan terhadap variabel laten yang lain, dapat disimpulkan bahwa data penelitian ini telah terpenuhi validitasnya.
Tabel 4

Hasil Uji Reliabilitas

\begin{tabular}{|c|c|c|c|c|c|c|c|}
\hline & PP & Patuh & Periksa & Tagih & AR & $\begin{array}{l}\mathrm{AR}^{*} \\
\text { Periksa }\end{array}$ & $\begin{array}{l}\mathrm{AR}^{*} \\
\text { Tagih }\end{array}$ \\
\hline $\begin{array}{l}\text { Composite } \\
\text { Reliability }\end{array}$ & 1,00 & 1,00 & 1,00 & 1,00 & 1,00 & 1,00 & 1,00 \\
\hline $\begin{array}{l}\text { Cronbach's } \\
\text { Alpha }\end{array}$ & 1,00 & 1,00 & 1,00 & 1,00 & 1,00 & 1,00 & 1,00 \\
\hline Rule of Thumb & & & & $>0,7$ & & & \\
\hline Reliabel/Tidak & Reliabel & Reliabel & Reliabel & Reliabel & Reliabel & Reliabel & Reliabe] \\
\hline
\end{tabular}

Berdasarkan tabel nilai composite reliability dan cronbach's alpha untuk masing-masing variabel indikator bernilai > 0,7 sehingga disimpulkan data penelitian ini telah reliabel.

Tabel 5

Hasil Uji Kecocokan Model (Godness of Fit)

\begin{tabular}{|ll|} 
& Nilai \\
\hline Average Path Coefficient & APC $=0,184, \mathrm{P}=0,015$ \\
\hline Average $R$-Squared & ARS $=0,158, P=0,027$ \\
\hline Tenenhaus GoF & GoF $=0,397$, small $>=0,1$, medium $=0,25$, large $=0,36$ \\
\hline Average Block VIF & AVIF $=1,492$, acceptable if $<=5$, ideally $<=3,3$ \\
\hline Sumber $:$ Data diolah tahun 2020
\end{tabular}

Koefisien determinasi dilakukan untuk mendeteksi ketepatan yang paling baik dalam analisis regresi ini, yaitu dengan membandingkan besarnya nilai koefisien determinan, jika $\mathrm{R}^{2}$ semakin besar mendekati 1 (Satu) maka model semakin tepat.

Menurut Ghozali (2011) besaran nilai $R$ Squared dapat dikategorikan menjadi 3 bagian yaitu : (1) kategori kuat nilai $R$-Squared $\geq$ 0,70 ; (2) kategori moderate nilai $R$-Squared antara $0,45 \mathrm{s.d}<0,70 ;(3)$ kategori lemah nilai $R$-Squared $\leq 0,25$. Nilai $R$-Squared penelitian ini adalah 0,158 , maka besaran nilai ini masuk kedalam kategori lemah, artinya penerimaan pajak yang dijelaskan melalui variabel kepatuhan pajak, pemeriksaan pajak, penagihan pajak dan moderasi peran AR sebesar $16 \%$, sedangkan sisanya $84 \%$ dijelaskan oleh variabel lain yang tidak diteliti dalam model penelitian ini.

Untuk memvalidasi model struktural secara keseluruhan digunakan Godness of Fit (GoF). Gof indeks merupakan ukuran tunggal untuk memvalidasi performa gabungan antara model pengukuran dan model struktural. Penelitian ini berada dalam kategori besar karena nilai GoF penelitian ini adalah 0,397.

Nilai Average Block VIF penelitian ini adalah 1,492, berarti model yang digunakan telah fit (Ratmono dan Sholihin, 2015:155). 
Hasil Uji Full Model

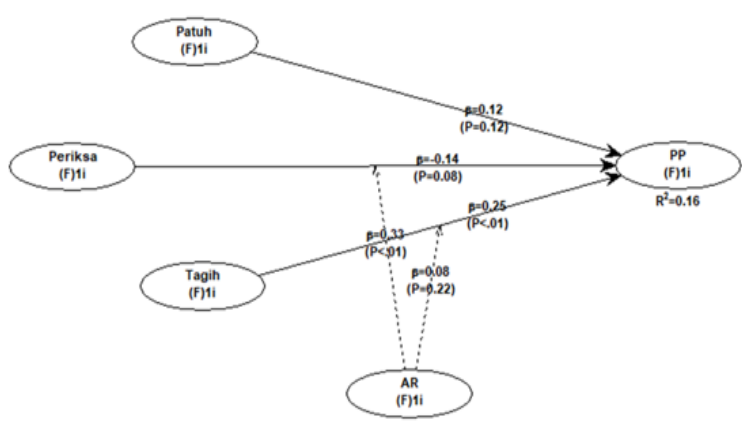

Gambar 2

Hasil Uji Full Model

1. Pengaruh Kepatuhan Terhadap Penerimaan Pajak

Kepatuhan wajib pajak adalah elemen penting dalam meningkatkan penerimaan pajak. Wajib pajak yang tidak patuh akan menimbulkan keinginan untuk melakukan tindakan penghindaran, pengelakan, penyelundupan dan pelalaian pajak.

Penelitian Mahendra \& Sukartha (2014) menunjukan bahwa peningkatan kepatuhan wajib pajak akan menyebabkan terjadinya peningkatan penerimaan pajak. Desideria \& Ngadiman (2019) dalam penelitiannya menunjukan bahwa tingkat kepatuhan wajib pajak meningkat seiring dengan meningkatnya penerimaan pajak. Demikian pula penelitian Yeni (2013) yang menunjukan bahwa peningkatan penerimaan pajak disebabkan oleh variabel tingkat kepatuhan wajib pajak badan yang melapor pada KPP Paratam Padang.

Berdasarkan hasil uji hipotesis variabel kepatuhan didapatkan bahwa nilai koefisien sebesar 0,12 dengan tingkat signifikan ( $P$-value) sebesar 0,12, dapat disimpulkan bahwa kepatuhan wajib pajak tidak berpengaruh terhadap penerimaan pajak karena nilai $P$-value $>10 \%$. Hal ini menunjukan bahwa hipotesis pertama ditolak.

Penelitian ini sejalan dengan penelitian Muhammad \& Sunarto (2018) yang menyimpulkan bahwa kepatuhan pajak tidak berpengaruh terhadap penerimaan pajak. Hal tersebut disebabkan oleh faktor lain yang tidak diteliti dalam penelitiannya seperti adanya wajib pajak yang lapor namun tidak mencantumkan sesuai dengan data yang sebenarnya dalam SPT nya. Penelitian Komarawati (2012) menunjukan bahwa kepatuhan wajib pajak tidak berpengaruh terhadap penerimaan pajak karena rasio penyampaian SPT Tahunan wajib pajak Orang Pribadi yang fluktuatif. Penelitian ini juga mendukung penelitian Alfian (2013) yang membuktikan bahwa kepatuhan tidak berpengaruh terhadap penerimaan pajak orang pribadi karena rasio wajib pajak yang membayar pajak di KPP Pratama Surabaya Krembangan masih fluktuatif. Alfian (2013) mengatakan bahwa dalam upaya meningkatkan penerimaan pajak, tidak cukup hanya kepatuhan wajib pajak sebagai faktor utama untuk meningkatkan penerimaan pajak. Misalnya pelayanan yang maksimal akan sangat menggugah hati masyarakat dalam kesediaannya membayar pajak.

Umumnya kepatuhan pajak yang meningkat akan diiringi dengan penerimaan pajak yang meningkat. Namun hal ini tidak terjadi di KPP PMA Enam. Berdasarkan data KPP PMA Enam tampak bahwa rasio kepatuhan wajib pajak atas pelaporan SPT Tahunan cenderung naik sejak tahun 2016, bahkan mencapai maksimal pada tahun 2018 yaitu 101\%, namun penerimaan pajak sejak tahun 2011 sampai dengan 2019 belum mencapai target.

Pengukuran kepatuhan wajib pajak yang digunakan dalam penelitian ini adalah kepatuhan formal yaitu dengan melihat jumlah SPT Tahunan PPh Badan dan SPT PPN yang dilaporkan, tanpa melihat jumlah pajak yang dibayarkan. Kepatuhan pelaporan tinggi menunjukkan wajib pajak peduli terhadap kewajiban pelaporan SPT karena wajib pajak memahami sanksi denda yang akan dikenakan jika tidak atau terlambat melaporkan SPT. Adanya mekanisme pembetulan SPT memungkinkan wajib pajak melaporkan SPT normalnya terlebih dahulu meskipun terdapat beberapa transaksi yang belum sepenuhnya terhitung untuk menghindari sanksi denda keterlambatan pelaporan SPT. Selain itu denda keterlambatan lebih mudah diterbitkan oleh Account Representative karena hanya meneliti 
tanggal pelaporan SPT. Sehingga peluang penerbitan STP atas keterlambatan lapor SPT lebih besar dibandingkan dengan peluang wajib pajak diperiksa.

KPP PMA Enam mengadministrasikan wajib pajak badan yang sahamnya dimiliki oleh pemilik asing baik perusahaan maupun perorangan, namun masih terdapat beberapa wajib pajak yang memiliki omzet kecil dibawah 4,8 Milyar dan belum memiliki Sumber Daya Manusia (SDM) yang kompeten di bidang perpajakan dan tidak menggunakan jasa konsultan pajak sehingga mempengaruhi pada pemenuhan kewajiban perpajakan yang dilakukan. Hal itu dapat menyebabkan wajib pajak hanya menjalankan kewajiban pajaknya yang familiar saja seperti pelaporan SPT karena belum atau tidak mengetahui lebih rinci kewajiban pajak yang terdapat dari transaksi yang dilakukan oleh wajib pajak. Hal ini menggambarkan kepatuhan wajib pajak tinggi namun penerimaan pajak belum tercapai.

Pemenuhan kewajiban formal pada wajib pajak KPP PMA Enam dapat tergambar dari data pemeriksaan yang telah dilakukan oleh KPP PMA Enam. Berdasarkan data tabel lampiran diketahui bahwa pada tahun 2016 terdapat 467 pemeriksaan dan menghasilkan 1.952 SKP. Tahun 2017 jumlah pemeriksaan pajak meningkat menjadi 497 pemeriksaan dengan menghasilkan Surat Ketetapan Pajak (SKP) yang diterbitkan sejumlah 4.571. Tahun 2017 meningkat sebanyak $6,5 \%$ dan SKP yang diterbitkan meningkat sebanyak 134\%. Tahun 2018 meningkat kembali sebanyak $17,1 \%$ menjadi sebanyak 582 pemeriksaan. Dari 582 pemeriksaan tersebut menghasilkan 9.898 SKP atau naik sekitar 116\%. Tujuan pemeriksaan pajak adalah menguji kepatuhan wajib pajak, banyaknya SKP yang dihasilkan dari pemeriksaan pajak menggambarkan bahwa meskipun wajib pajak melaporkan SPT tepat waktu namun wajib pajak belum melaporkan besar pajak yang terutang sesuai kondisi sebenarnya sehingga kepatuhan pelaporan pajak di KPP PMA Enam tidak berbanding lurus dengan penerimaan pajak.
Selain kapatuhan formal, terdapat beberapa faktor eksternal yang mempengaruhi penerimaan pajak misalnya kondisi perdagangan international yang turun. Wajib pajak KPP PMA Enam banyak memiliki transaksi dengan wajib pajak lintas negara, sehingga banyak kegiatan ekspor dan impor. Menurunnya perdagangan international berdampak pada menurunnya penerimaan pajak PPN atau PPN impor yang dihimpun oleh KPP PMA Enam.

Rendahnya daya beli masyarakat dibidang properti juga mempengaruhi penerimaan karena KPP PMA Enam mengadminsitrasikan wajib pajak yang memiliki bidang usaha properti real estate.

Selain itu berbagai kebijakan pemerintah seperti tax amnesty yang pernah diterbitkan oleh pemerintah pada tahun 2015 ikut mempengaruhi penerimaan pajak, karena pemeriksa pajak tidak dapat melakukan pemeriksaan pajak untuk tahun pajak 2015 dan sebelumnya kepada wajib pajak yang memanfaatkan program tax amnesty. Account Representative kehilangan potensi pajak dari kegiatan penelitian dan penagihan pajak kehilangan potensi pajak dari STP dan SKP yang telah dihapuskan karena wajib pajak memanfaatkan program tax amnesty. Kendala-kendala tersebut menunjukan bahwa terdapat banyak faktor yang lebih mempengaruhi penerimaan pajak di KPP PMA Enam.

2. Pengaruh Pemeriksaan Terhadap Penerimaan Pajak

Penelitian Primerdo (2015) menunjukan bahwa pemeriksaan pajak berpengaruh efektif terhadap penerimaan pajak apabila dilakukan terhadap wajib pajak yang terindikasi melakukan kecurangan dalam melaporkan besarnya pajak yang terutang.

Hasil uji hipotesis kedua pada variabel pemeriksaan menunjukan bahwa nilai koefisien pemeriksaan sebesar $-0,14$ dengan nilai $P$-value sebesar 0,08 , dapat disimpulkan bahwa pemeriksaan pajak berpengaruh negatif terhadap penerimaan pajak karena nilai $P$-value $<10 \%$. Hal ini menunjukan bahwa hipotesis kedua diterima. 
Penelitian ini sejalan dengan penelitian Monica \& Andi (2019) dan Primerdo (2015) yang menyatakan bahwa pemeriksaan pajak akan lebih efektif apabila dilakukan terhadap wajib pajak yang terindikasi melakukan kecurangan dalam melaporkan besarnya pajak yang terutang.

Pemeriksaan pajak yang seharusnya diharapkan mampu memberikan kontribusi positif yang signifikan terhadap penerimaan pajak, ternyata menunjukan hal yang sedikit berbeda dalam penelitian kali ini. Berdasarkan data laporan hasil pemeriksaan pajak diketahui jumlah pemeriksaan pajak KPP PMA Enam meningkat dari tahun ke tahun begitu pula dengan SKP yang dihasilkan dari pemeriksaan pajak. Bahkan pada tahun 2017 dan 2018 SKP bertambah lebih dari 2 kali lipat dari tahun sebelumnya dan diiringi dengan meningkatnya jumlah SKP yang diajukan keberatan oleh wajib pajak. Pada tahun 2016 KPP PMA Enam menerbitkan 1.952 Surat Ketetapan dengan jumlah surat ketetapan yang diajukan keberatan sebanyak 66 ketetapan. Tahun 2017 Surat ketetapan pajak yang terbit meningkat menjadi 4.571 dengan jumlah surat ketetapan pajak yang diajukan keberatan sebanyak 575 ketetapan atau sekitar 771\%. Tahun 2018 SKP yang diterbitkan meningkat 116\% menjadi 9.898 surat ketetapan dengan jumlah surat ketetapan yang diajukan keberatan sebanyak 553 ketetapan. Pengajuan keberatan merupakan salah satu upaya hukum yang dapat diajukan wajib pajak untuk mempertahankan pendapat wajib pajak terkait hitungan besarnya pajak yang terutang. Permohonan keberatan yang dilakukan oleh wajib pajak menggambarkan bahwa besarnya pajak terutang yang ditetapkan berdasarkan hasil pemeriksaan pajak tidak sepenuhnya disetujui oleh wajib pajak.

Meningkatnya jumlah pemeriksaan pajak tidak diiringi dengan tercapainya target penerimaan pajak yang dibebankan kepada KPP PMA Enam. Berdasarkan data penerimaan pajak sebagaimana telah dipaparkan dalam penelitian ini terlihat bahwa sejak tahun 2011 realisasi netto
KPP PMA Enam tidak mencapai target bahkan realisasi bruto hanya mencapai target pada tahun 2013. Besarnya restitusi pajak sangat mempengaruhi penerimaan pajak di KPP PMA Enam. Rrestitusi pajak mengurangi sebesar 5\%-11\% dari total penerimaan pajak yang dicapai oleh KPP PMA Enam pada tahun 2017-2019. Restitusi terbesar terjadi pada tahun 2019 yaitu mengurangi $10,51 \%$ atau sebesar $R p$ 1.276.295.000,- dari total bruto penerimaan pajak tahun 2019 sebesar Rp 12.142.340.000,-.

Restitusi pajak di KPP PMA Enam sebagian besar berasal dari hasil keberatan maupun banding yang dimenangkan oleh wajib pajak. Dengan kata lain bahwa perhitungan pajak terutang yang tercantum dalam SKP hasil pemeriksaan pajak yang disetujui adalah berdasarkan perhitungan wajib pajak.

Perbedaan perhitungan pajak terutang menurut wajib pajak dan pemeriksaan pajak terjadi karena pada saat pemeriksaan pajak, wajib pajak tidak dapat melengkapi dokumen pendukung yang diperlukan atau tidak dapat memberikan bukti terkait transaksi yang menjadi koreksi pemeriksa pajak.

Upaya hukum dilakukan oleh wajib pajak untuk mempertahankan pendapat wajib pajak tentang besarnya pajak yang terutang dengan melampirkan bukti pendukung yang lebih lengkap. Dan beberapa upaya hukum yang dilakukan oleh wajib pajak dikabulkan pada tingkat keberatan atau banding.

Banyaknya upaya hukum yang dimenangkan wajib pajak membuat wajib pajak antipati terhadap pemeriksaan pajak sehingga wajib pajak enggan untuk membayar pajak. Dapat dikatakan bahwa pemeriksaan pajak di KPP PMA Enam belum efektif dan belum fokus pada pemeriksaan yang memiliki potensi pajak besar dan yang seharusnya dibayar oleh wajib pajak yang tidak menimbulkan sengketa sehingga tidak akan diajukan upaya hukum oleh wajib pajak.

3. Pengaruh Pemeriksaan Pajak Terhadap Penerimaan Pajak Yang Dimoderasi oleh Peran Account Representative 
Pemeriksaan pajak merupakan upaya untuk mengantisipasi kemungkinan terjadinya penyelewengan oleh wajib pajak yang telah diberi kepercayaan self assessment agar peraturan perpajakan dapat dilakukan sebagaimana mestinya. Pemeriksaan pajak dapat menentukan tambahan pajak yang masih harus dibayar oleh wajib pajak.

Account Representative yang berkompeten memiliki kemampuan dalam menguasai peraturan perpajakan, mampu manganalisa laporan keuangan wajib pajak, mengetahui perkembangan usaha serta memiliki seni komunikasi yang baik. Kompetensi tersebut digunakan oleh Account Representative dalam melakukan penggalian potensi pajak guna meningkatkan penerimaan pajak. Pemeriksaan pajak dan himbauan yang diterbitkkan oleh Account Representative merupakan strategi dalam pengamanan penerimaan pajak.

Penelitian Ramadhana

menunjukan bahwa kompetensi Account Representative berpengaruh signifikan terhadap terhadap strategi pengamanan penerimaan pajak. Boroh \& Mursalim (2018) dalam penelitiannya membuktikan bahwa kompetensi Account Representative berpengaruh signifikan terhadap penerimaan pajak. Penelitian lain oleh Wahyuni (2015) menunjukan bahwa kinerja Account Representative berpengaruh positif yang signifikan terhadap efektivitas penerimaan pajak.

Pada hipotesis kedua (H2) telah dibuktikan bahwa terdapat pengaruh antara pemeriksaan terhadap penerimaan pajak, namun sebagai keterbaharuan penelitian maka penulis mencoba menghubungkan apakah pemeriksaan dapat mempengaruhi penerimaan pajak dengan dimoderasi oleh peran Account Representative karena himbauan yang diterbitkan merupakan salah satu strategi dalam menghimpun penerimaan pajak.

Hasil uji hipotesis ketiga (H2a) pada variabel pemeriksaan yang dimoderasi oleh peran Account Representative menunjukan nilai koefisien sebesar 0,33 dengan nilai $P$-value sebesar $<0,01$, dapat disimpulkan bahwa pemeriksaan pajak yang dimoderasi oleh peran Account Representative berpengaruh terhadap penerimaan pajak karena nilai $P$-value $<$ $10 \%$, Dengan demikian hipotesis ketiga diterima.

Hasil uji pengaruh langsung pemeriksaan terhadap penerimaan pajak sebelumnya menyatakan bahwa pemerikaan pajak berpengaruh negatif terhadap penerimaan pajak. Telah disampaikan pula bahwa pengaruh negatif diakibatkan oleh banyaknya upaya hukum wajib pajak yang dimenangkan oleh wajib pajak pada tingkat keberatan dan banding sehingga membuat wajib pajak antipati terhadap pelaksanaan pemeriksaan pajak dan membuat wajib pajak enggan untuk melakukan pembayaran pajak.

Hasil uji pengaruh tidak langsung pemeriksaan terhadap penerimaan pajak yang dimoderasi oleh Account Representative menunjukan pengaruh yang positif. Hasil ini berarti peran Account Representative dalam menerbitkan Surat Himbauan kepada wajib pajak mampu mendorong dan memperkuat pemeriksaan pajak dalam meningkatkan penerimaan pajak.

Account Representative bertugas memberikan edukasi dan penyuluhan terkait kewajiban perpajakan kepada wajib pajak. Tindakan persuasif yang dilakukan oleh Account Representative mengubah pandangan wajib pajak terhadap kewajiban perpajakan yang harus dilakukannya. Wajib Pajak lebih peduli pada pelaporan SPTnya serta sanksi dan denda yang akan timbul jika wajib pajak tidak melaporkan SPT dengan benar.

Apabila wajib pajak diperiksa, besarnya pajak terutang dihitung berdasarkan besarnya pajak yang kurang dibayar ditambah dengan dengan sanksi administrasi berupa bunga, kenaikan dan atau denda. Sedangkan apabila wajib pajak dihimbau oleh Account Representative dan wajib pajak kooperatif maka besarnya pajak yang seharusnya dibayar dari hasil himbauan hanya sebesar pajak yang kurang dibayar ditambah dengan sanksi administrasi berupa bunga. Sehingga besarnya pajak yang harus dibayar dari hasil himbauan Account Representative 
akan lebih kecil dibandingkan dengan hasil pemeriksaan karena tidak dikenakan sanksi administrasi berupa kenaikan yang besarnya sebesar $100 \%$ dari pajak yang kurang dibayar. Semakin kecil sanksi dan denda yang dikenakan, maka semakin kecil biaya yang akan dikeluarkan oleh wajib pajak sehingga menguntungkan wajib pajak. Dalam jangka panjang, surat himbauan serta edukasi yang disampaikan Account Representative tentang pemeriksaan pajak akan berdampak pada meningkatnya kesadaran wajib pajak dalam menjalankan kewajiban perpajakannya karena wajib pajak akan memilih untuk menjalankan kewajiban perpajakan sesuai ketentuan dibandingkan harus dilakukan pemeriksaan pajak dan dikenakan sanksi yang lebih besar.

Data KPP PMA Enam tahun 2018 menunjukan bahwa terdapat 179 surat himbauan SPT Tahunan dan 1.256 Surat Himbauan SPT Masa yang diterbitkan Account Representative. Selain itu terdapat 3.628 Surat Tagihan Pajak yang diterbitkan oleh Acoount Representative.

4. Pengaruh Penagihan Pajak Terhadap Penerimaan Pajak

Penagihan pajak adalah proses yang dilakukan DJP dalam memberikan tekanan kepada wajib pajak untuk melunasi utang pajaknya. Tindakan ini dilakukan karena wajib pajak tidak mematuhi aspek material peraturan perundang-undangan perpajakan (Rahayu, 2017:295). Pencairan tunggakan pajak akan secara otomatis menambah jumlah penerimaan pajak yang dihimpun.

Mahendra \& Sukartha (2014) dalam penelitiannya menunjukan bahwa peningkatan penagihan pajak akan menyebabkan terjadinya peningkatan penerimaan pajak penghasilan badan. Penelitian Meiliawati (2013) menunjukan bahwa setiap kenaikan pencairan tunggakan pajak sebesar $1 \%$ akan menyebabkan peningkatan penerimaan pajak ada KPP Pratama Kosambi sebesar 1.874. Penelitian Lubis (2019) menunjukan bahwa surat teguran dan surat paksa yang merupakan produk dari penagihan pajak memiliki pengaruh terhadap penerimaan pajak karena penerbitan surat teguran dan surat paksa untuk wajib pajak yang memiliki tunggakan pajak ternyata diikuti dengan peningkatan penerimaan pajak dari sektor tunggakan pajak.

Hasil uji hipotesis keempat (H3) pada variabel penagihan menunjukan bahwa nilai koefisien penagihan sebesar 0,25 dengan nilai $P$-value sebesar $<0,01$, dapat disimpulkan bahwa penagihan pajak berpengaruh terhadap penerimaan pajak karena nilai $P$-value $<10 \%$. Hal ini menunjukan bahwa hipotesis Keempat diterima.

Penelitian ini konsisten dengan penelitian sebelumnya yaitu penelitian Meiliawati (2013) yang menyimpulkan bahwa penagihan pajak memiliki pengaruh yang signifikan terhadap penerimaan pajak yang dilihat dari pencairan tunggakan pajak. Begitu pula dengan penelitian Muhammad \& Sunarto (2018) yang mengatakan bahwa penagihan pajak berpengaruh positif terhadap penerimaan pajak periode 2012-2015. Monica \& Andi (2019) dalam penelitiannya menunjukan bahwa pencairan tunggakan pajak berpengaruh positif secara signifikan terhadap penerimaan pajak badan, semakin banyak jumlah tunggakan pajak yang dapat dicairkan maka akan semakin menambah jumlah penerimaan pajak badan yang dapat dihimpun.

Kegiatan penagihan pajak memiliki peran dalam mengamankan target penerimaan pajak. Berdasarkan data KPP PMA Enam, sepanjang tahun 2018 capaian pencairan piutang pajak mencapai $289 \%$ dari target yang ditetapkan oleh instansi sebesar 90 milyar. Berdasarkan data sampel terdapat 68 sampel yang telah melakukan pembayaran atas tunggakan pajak, 43 sampel diantaranya telah melunasi tunggakan pajak.

Berbagai capaian telah diperoleh oleh KPP PMA Enam dari kegiatan penagihan pajak. Pada tahun 2018 telah melakukan penyitaan aset wajib pajak dan atau penanggung pajak dengan total nilai perkiraan aset sekitar Rp 26 milyar. Dan pencairan aset hasil lelang mencapai $\mathrm{Rp}$ 1,8 milyar. Pada tahun 2018 berhasil melakukan pencegahan terhadap penanggung pajak kepada 10 penanggung 
pajak dan tindakan ini berhasil mencairkan piutang pajak sebesar $\mathrm{Rp} 8,5$ milyar.

Upaya penagihan yang dilakukan oleh KPP PMA Enam telah menghasilan pencairan tunggakan pajak yang sangat berkontribusi menambah penerimaan pajak. Hal ini menunjukan bahwa penagihan pajak berpengaruh positif terhadap penerimaan pajak di KPP PMA Enam.

5. Pengaruh Penagihan Pajak Terhadap Penerimaan Pajak yang Dimoderasi oleh Peran Account Representative

Hasil uji hipotesis kelima (H3a) menunjukan bahwa nilai koefisien penagihan yang dimoderasi oleh peran Acoount Representaive sebesar 0,08 dengan nilai $P$-value sebesar 0,22 , dapat disimpulkan bahwa penagihan pajak yang dimoderasi oleh peran Account Representative tidak berpengaruh terhadap penerimaan pajak karena nilai $P$-value $>$ $10 \%$, dengan demikian hipotesis kelima ditolak.

Sebagian utang pajak yang diterbitkan adalah atas STP yang diterbitkan oleh Acoount Representative. STP diterbitkan karena wajib pajak terlambat melakukan pembayaran dan pelaporan pajak. Nilai STP yang diterbitkan hanya menghitung jumlah bulan keterlambatan pembayaran pajak atau dihitung dari telat atau tidaknya pelaporan SPT yang dilakukan oleh wajib pajak, sehingga nilai STP yang diterbitkan lebih kecil karena tidak menghitung jumlah pajak yang kurang dibayar. Meskipun demikian, pelunasan utang pajak dari hasil pembayaran STP yang dilakukan oleh wajib pajak akan menambah penerimaan pajak. Berdasarkan data KPP PMA Enam tahun 2018, STP yang berhasil diterbitkan oleh Account Representative berjumlah 3.628 STP yang akan berpotensi meningkatkan penerimaan pajak.

Namun berdasarkan data penagihan pajak, KPP PMA Enam telah menerbitkan 1.715 surat teguran terkait pembayaran tunggakan pajak. Hal ini menunjukan bahwa wajib pajak belum membayarkan tunggakan pajak sesuai tanggal jatuh tempo pembayaran tunggakan pajak. Tahun 2018 telah diterbitkan 918 surat paksa dan 20 surat pelaksanaan penyitaan. Kegiatan penagihan telah membuat 9 Berita Acara pemblokiran dan telah melakukan pencegahan terhadap 10 penunggak pajak. Kegiatan penagihan ini menunjukan bahwa beberapa wajib pajak diragukan itikad baiknya dalam melunasi utang pajak atau tidak kooperatif ketika pelaksanaan penagihan pajak.

Hasil ini menunjukan bahwa penagihan pajak yang dimoderasi oleh peran Account Representative tidak berpengaruh terhadap penerimaan pajak karena tindakan penagihan pajak muncul dari konsekuensi ketika wajib pajak tidak bersedia melunasi sebagian atau seluruhnya utang pajaknya. Hal ini dilakukan kepada wajib pajak atau penanggung pajak yang tidak kooperatif atau menghindar dari kewajiban pelunasan pajak, serta tidak menghiraukan himbauan atau edukasi yang diberikan oleh Account Representative.

\section{Kesimpulan, Keterbatasan dan Implikasi Hasil Penelitian}

Berdasarkan data penelitian dan hasil penelitian, dapat disimpulkan hal-hal sebagai berikut :

1. Kepatuhan wajib pajak tidak berpengaruh terhadap penerimaan pajak. Perhitungan kepatuhan dalam penelitian ini berdasarkan kepatuhan formal wajib pajak yaitu hanya berdasarkan pelaporan SPT tanpa melihat kepatuhan material terkait kebenaran jumlah pajak terutang yang tercantum dalam SPT. Minimnya SDM yang kompeten di bidang perpajakan atau tidak menggunakan jasa konsultan pajak dapat mempengaruhi pemenuhan kewajiban perpajakan yang dilakukan oleh wajib pajak. Penerimaan pajak juga dipengaruhi oleh faktor lain yang tidak diteliti dalam penelitian ini, misalnya kondisi perdagangan international yang mempengaruhi kegiatan ekspor impor, rendahnya daya beli masyarakat dibidang properti, serta kebijakan tax amnesty.

2. Pemeriksaan pajak berpengaruh negatif terhadap penerimaan pajak. Hal tersebut disebabkan karena banyaknya upaya 
hukum wajib pajak yang dimenangkan oleh wajib pajak pada tingkat keberatan dan banding sehingga membuat wajib pajak antipati terhadap pelaksanaan pemeriksaan pajak dan membuat wajib pajak enggan untuk melakukan pembayaran pajak. Besarmya restitusi dari hasil upaya hukum wajib pajak juga mempengaruhi penerimaan pajak karena restitusi pajak mengurangi sebesar 5\% $11 \%$ dari total penerimaan pajak yang dicapai oleh KPP PMA Enam pada tahun 2017-2019. Dapat dikatakan bahwa pemeriksaan pajak di KPP PMA Enam belum efektif dan belum fokus pada pemeriksaan yang memiliki potensi pajak besar dan yang seharusnya dibayar oleh wajib pajak yang tidak menimbulkan sengketa sehingga tidak akan diajukan upaya hukum oleh wajib pajak.

3. Pemeriksaan Pajak yang dimoderasi oleh Peran Account Representative berpengaruh terhadap penerimaan pajak. Hal ini menunjukan bahwa peran Account Representative dalam menerbitkan Surat Himbauan mampu mendorong dan memperkuat pemeriksaan pajak dalam meningkatkan penerimaan pajak. Tindakan persuasif yang dilakukan oleh Account Representative mengubah pandangan wajib pajak terhadap kewajiban perpajakan sehingga lebih peduli pada pelaporan SPTnya serta sanksi dan denda yang akan timbul jika wajib pajak tidak melaporkan SPT dengan benar.

4. Penagihan pajak berpengaruh terhadap penerimaan pajak. Hal ini menunjukan bahwa pelunasan tunggakan pajak yang dilakukan oleh wajib pajak dapat menjadi salah satu faktor yang menyumbang penerimaan pajak. Berbagai upaya penagihan telah dilakukan oleh KPP PMA Enam sehingga menghasilan pencairan tunggakan pajak dari beberapa penunggak pajak dan penanggung pajak yang berkontribusi menambah penerimaan pajak. Hal tersebut terlihat dari besarnya pencairan tunggakan pajak yang mencapai
$289 \%$ dari target yang ditetapkan oleh instansi.

5. Penagihan pajak yang dimoderasi oleh peran Account Representative tidak berpengaruh terhadap penerimaan pajak. Hasil ini menunjukan bahwa penagihan pajak yang dimoderasi oleh peran Account Representative tidak berpengaruh terhadap penerimaan pajak karena tindakan penagihan pajak muncul dari konsekuensi ketika wajib pajak tidak bersedia melunasi sebagian atau seluruhnya utang pajaknya. Hal ini dilakukan kepada wajib pajak atau penanggung pajak yang tidak kooperatif atau menghindar dari kewajiban pelunasan pajak yang menjadi tanggungannya, serta tidak menghiraukan himbauan atau edukasi yang diberikan oleh Account Representative.

Saran Untuk Peneliti Selanjutnya :

a. Berdasarkan bukti empiris, penelitian ini dapat dijadikan referensi penelitian selanjutnya dan dikembangkan lagi dengan menambahkan objek penelitian yang lebih luas, sampel penelitian yang lebih banyak, serta rentan waktu yang lebih lama sehingga hasil penelitian lebih menggambarkan kondisi jangka panjang dari faktor-faktor yang digunakan sebagai variabel penelitian.

b. Peneliti dapat mengembangkan penelitian ini dengan menggunakan skala pengukuran yang berbeda guna mendapatkan hasil penelitian dari sudut pandang yang berbeda.

c. Bagi peneliti selanjutnya dapat menambah variabel baru dari faktor eksternal seperti pertumbuhan ekonomi, kebijakan pemerintah, kondisi usaha baik didalam negeri maupun kondisi perdagangan international.

Saran Untuk Praktisi :

a. Account Representative sebagai ujung tombak penerimaan pajak agar selalu memberikan edukasi, penyuluhan, serta pemahaman terkait peraturan perpajakan sehingga wajib pajak lebih memahami kewajiban perpajakannya. 
b. Account Representative dan pemeriksa pajak agar memperluas penjelajahan dalam pencairan data dari berbagai sumber internal maupun eksternal sehingga memperoleh lebih banyak data yang memiliki potensi untuk meningkatkan penerimaan pajak.

c. Account Representative dan Pemeriksa Pajak agar memperluas pengetahuannya perpajakan yang berlaku dan diterapkan di negara-negara lain sehingga menambah pengetahuan tentang perpajakan dari aspek international, proses bisnis international serta data transaksi international antara wajib pajak dengan lawan transaksinya yang berada diluar negara Indonesia.

d. Pemeriksa pajak agar melakukan pemeriksaan berfokus pada potensi pajak yang nyata belum terbayar sehingga pelaksanaan pemeriksaan pajak lebih efektif sehingga tidak ada sengketa dan mengurangi upaya hukum yang dilakukan wajib pajak.

e. Dalam upaya meningkatkan penerimaan pajak KPP PMA Enam dapat menerapkan sanksi tegas dan berat bagi wajib pajak yang tidak jujur dalam pengisian SPT.

f. Penagihan pajak seketika dan sekaligus lebih giat dilakukan kepada para penunggak pajak yang terindikasi akan menghindari kewajiban perpajakannya sehingga potensi penerimaan pajak dari hasil pencairan tunggakan pajak dapat terealiasi.

g. KPP PMA Enam dapat memberikan penghargaan kepada wajib pajak yang patuh dalam pembayaran dan pelaporan pajak. Hal tersebut dapat memacu wajib pajak untuk lebih peduli pada kewajiban perpajakannya, sehingga melakukan pelaporan dan pembayaran pajak dengan benar merupakan keharusan tanpa beban.

h. Pemerintah agar memperluas dalam menjalin kerjasama dengan pihak lain terkait pertukaran data transaksi wajib pajak sehingga KPP PMA Enam memiliki akses yang lebih luas yang dapat digunakan untuk penggalian potensi pajak.

\section{Daftar Pustaka}

Alfian, R. (2013). Pengaruh Kepatuhan Wajib Pajak Orang Pribadi Terhadap Penerimaan Pajak di KPP Pratama Surabaya Krembangan. Jurnal Akuntansi AKUNESA, 1(3).

Boroh, C. S., \& Mursalim. (2018). Pengaruh Pemahaman Peraturan Perpajakan , Kesadaran Wajib Pajak dan Kompetensi Account Representative terhadap Penerimaan Pajak ( Studi Kasus KPP Madya Makassar ). 2(2), 23-35.

Burton \& Ilyas, M. (2013). Hukum Pajak, Edisi 6. Jakarta: Salemba Empat.

Donaldson, L., \& Davis, J. H. (1991). Stewardship theory or agency theory: CEO governance and shareholder returns. Australian Journal of management, 16(1), 49-64.

Elvina Desideria, N. (2019). Faktor-Faktor Yang Mempengaruhi Penerimaan Pajak Dari Wajib Pajak Badan Tahun 20162017. Jurnal Paradigma Akuntansi, 1(2), 355-363.

Ghozali, I. (2006). Analisis Multivariat dengan program SPSS, cetakan ke-4. Semarang: Badan Penerbit Universitas Diponegoro.

Ghozali, I. (2011). Aplikasi Analisis Multivariate Dengan Program SPSS. Semarang: Badan Penerbit Universitas Diponegoro.

Gunadi. (2013). Panduan Komprehensif Pajak Penghasilan, Edisi 2013. Jakarta: Bee Media Indonesia.

Hanif, R. A., Satriawan, R. A., \& Sari, W. P.Pengaruh Kesadaran Wajib Pajak, Kegiatan Sosialisasi Perpajakan, Pemeriksaan Pajak dan Jumlah Wajib Pajak yang Terdaftar terhadap Penerimaan Pajak Penghasilan Orang Pribadi di Kpp Pratama Pekanbaru Tampan (Doctoral dissertation, Riau University).

Hidayat, N. (2013). Pemeriksaan Pajak. Jakarta: Elex Media Komputindo. 
Hutagaol, J. (2007). Perpajakan: Isu-isu Kontemporer. Yogyakarta: Graha Ilmu.

Kastolani, O. J. Y., \& Ardiyanto, M. D. (2017). Pengaruh Tingkat Kepatuhan Wajib Pajak dan Pemeriksaan terhadap Penerimaan Pajak Penghasilan. Diponegoro Journal of Accounting, 6(3), 669-679.

Komarawati, D. R. (2012). Analisis Tingkat Kepatuhan Wajib Pajak Orang Pribadi Terhadap Tingkat Penerimaan Pajak Di Kabupaten Lahat. InFestasi (Jurnal Bisnis dan Akuntansi), 8(1), 33-44.

Lubis, F. K. (2019). Pengaruh penagihan pajak aktif terhadap penerimaan pajak di Kantor Pelayanan Pajak Pratama Medan Belawan. Jurnal Riset Akuntansi Multiparadigma, 6(1), 22-28.

Mahendra, P. P., \& Sukartha, I. M. (2014). Pengaruh Kepatuhan, Pemeriksaan, dan Penagihan Pajak Pada Penerimaan Pajak Penghasilan Badan. E-Jurnal Akuntansi Universitas Udayana, 3, 633-643.

Meiliawati, A. (2013). Pengaruh Pemeriksaan dan Penagihan Pajak Terhadap Penerimaan Pajak Pada KPP Pratama Kosambi. Ultimaccounting: Jurnal Ilmu Akuntansi, 5(1), 1-18.

Monica, R., \& Andi. (2019). Pengaruh Kepatuhan Wajib Pajak, Pemeriksaan Pajak, Dan Pencairan Tunggakan Pajak Terhadap Penerimaan Pajak Badan Pada Kantor Pelayanan Pajak Pratama Serang Tahun 2012-2016. Jurnal Riset Akuntansi Terpadu, 12(1), 64-82.

Nurmantu, S. (2005). Pengantar perpajakan. Yayasan Obor Indonesia.

Nurmantu, S. Pengantar Perpajakan. 2003. Jakarta: Granit.

Parmono, F. V. (2016). Analisis Efektivitas Surat Himbauan Atau Surat Permintaan Penjelasan Atas Data Atau Keterangan (Sp2dk) terhadap Penerimaan Pajak pada Kpp Pratama Manado. Jurnal EMBA: Jurnal Riset Ekonomi, Manajemen, Bisnis dan Akuntansi, 4(1).
Primerdo, R. Y., \& Aris, M. A. (2015). Pengaruh pemeriksaan pajak dan penagihan pajak terhadap efektivitas penerimaan pajak (studi kasus pada KPP Pratama Surakarta) (Doctoral dissertation, Universitas Muhammadiyah Surakarta).

Rahayu, S. K. (2017). Perpajakan (konsep dan aspek formal). Bandung: Rekayasa Sains.

Ramadhana, I. (2016). Pengaruh Kompetensi dan Independensi Account Representative Terhadap Strategi Pengamanan Penerimaan Pajak Pada Kantor Pelayanan Pajak Kota Palembang. Jurnal Penelitian Dan Pengembangan AKuntansi, 10(2), 155-166.

Ratmono, D. (2017). Akuntansi keuangan daerah berbasis akrual.

Sakti, S. S. K. (2019). Pengaruh Pemeriksaan Pajak, Penagihan Pajak, Dan Kepatuhan Wajib Pajak Terhadap Penerimaan Pajak Pribadi (Studi Wajib Pajak Orang Pribadi pada KPP Pratama Temanggung) (Doctoral dissertation, Universitas Pembangunan Nasional Veteran Yogyakarta).

Soenaryo, N. (2017). Pengaruh jumlah wajib pajak, kepatuhan pajak, pemeriksaan pajak dan penagihan pajak terhadap penerimaan pajak penghasilan badan (Doctoral dissertation, Universitas Multimedia Nusantara).

Sultan. (2013). Pengaruh Penagihan Pajak dan Kepatuhan Wajib Pajak Terhadap Penerimaan Pajak di Kantor Wiayah Direktorat Jenderal Pajak Sulawesi Selatan, Barat dan Tenggara. Universitas Muslim Indonesia.

Sunarto, S., \& Muhammad, A. (2018). Pengaruh Pemeriksaan Pajak, Penagihan Pajak, Dan Kepatuhan Wajib Pajak Terhadap Penerimaan Pajak Studi Kasus Pada Kpp Pratama Raba Bima Tahun 2012-2015. Akuntansi Dewantara, 2(1), $37-45$.

Trisnayanti, I. A. I. (2015). Pengaruh Self Assessment System, Pemeriksaan Pajak, 
dan Penagihan Pajak pada Penerimaan Pajak Pertambahan Nilai (PPN). Akuntansi Universitas Udayana, 1, 292-310.

Wahyuni, R. N. (2015). Pengaruh Modernisasi Administrasi Perpajakan Dan Kinerja Account Representative (Ar) Terhadap Efektivitas Penerimaan Pajak: Survey Pada Kantor Pelayanan Pajak Pratama Se-Bandung Raya Di Wilayah Jawa Barat 1 (Doctoral dissertation, Universitas Pendidikan Indonesia)..
Wulandari, R. (2015). Faktor-Faktor Yang Mempengaruhi Penerimaan Pajak Penghasilan Pada KPP Pratama. Perbanas Review, 1(01).

Yeni, R. (2013). Pengaruh Tingkat Kepatuhan Wajib Pajak Badan Terhadap Peningkatan Penerimaan Pajak Yang Dimoderasi Oleh Pemeriksaan Pajak Pada KPP Pratama Padang. Jurnal Akuntansi, 1(1). 